\title{
Ambient ozone over mid-Brahmaputra Valley, India: effects of local emissions and atmospheric transport on the photostationary state
}

\author{
Warisha Rahman • Gufran Beig • \\ Nivedita Barman · Philip K. Hopke • \\ Raza R. Hoque (i)
}

Received: 27 April 2021 / Accepted: 26 October 2021 / Published online: 11 November 2021

(C) The Author(s), under exclusive licence to Springer Nature Switzerland AG 2021

\begin{abstract}
This study presents the characteristics of ground level atmospheric ozone $\left(\mathrm{O}_{3}\right)$ over the rural mid-Brahmaputra Valley region of the northeastern India. Ozone and oxides of nitrogen $\left(\mathrm{NO}_{\mathrm{x}}=\mathrm{NO}+\mathrm{NO}_{2}\right)$ concentration data were obtained from continuous measurement of $\mathrm{O}_{3}$ and $\mathrm{NO}_{\mathrm{x}}$ housed at the MAPAN-AQM station at Tezpur University. The meteorological parameters were obtained from the same station. The diel, monthly, and seasonal variations of $\mathrm{O}_{3}$ were studied. The $\mathrm{O}_{3}-\mathrm{NO}_{x}$ photostationary state $(P S)$ was carefully examined and it was found that the net $\mathrm{O}_{3}$ concertation deviated substantially from the $P S$ during the winter season. The
\end{abstract}

Supplementary information The online version contains supplementary material available at https://doi. org/10.1007/s10661-021-09572-3.

W. Rahman · N. Barman $\cdot$ R. R. Hoque $(\bowtie)$

Department of Environmental Science, Tezpur University, Tezpur 784028, India

e-mail: rrh@tezu.ernet.in

G. Beig

Indian Institute of Tropical Meteorology, 411004 Pune, India

P. K. Hopke

Department of Public Health Sciences, University

of Rochester Medical Center, Rochester, NY 14642, USA

P. K. Hopke

Center for Air Resources Engineering and Science,

Clarkson University, Potsdam, NY 13699, USA deviation could be attributed to local biomass burning, biogenic VOC emission from forest and agriculture, and long-range transport of peroxyacyl nitrate (PAN). The long-range transport has been ascertained by examining the ventilation coefficients (VC), which correlated with the steep growth of net $\mathrm{O}_{3}$ concentrations in the morning hours. The HYSPLIT air mass back trajectories were used in concentration-weighted trajectory (CWT) analyses of $\mathrm{O}_{3}$ to assess the longrange regional transport of $\mathrm{O}_{3}$ precursors, which positively influenced local $\mathrm{O}_{3}$ concentrations.

Keywords Ambient $\mathrm{O}_{3} \cdot \mathrm{NO}_{\mathrm{x}} \cdot$ Photostationary state $\cdot$ HYSPLIT $\cdot$ Concentration-weighted trajectories

\section{Introduction}

Ground level atmospheric ozone $\left(\mathrm{O}_{3}\right)$ is a criteria air pollutant and a major component of photochemical smog. Its formation depends on the chemistry of the precursors, viz., oxides of nitrogen $\left(\mathrm{NO}_{\mathrm{x}}=\mathrm{NO}_{2}+\mathrm{NO}\right)$, volatile organic compounds (VOC), and related species like carbon monoxide (CO), and prevailing meteorological conditions like solar radiation, air temperature, and wind (e.g., Allu et al., 2020; Geddes et al., 2009; HaagenSmit, 1952; Khalil et al., 2018; Leighton, 1961; Paoletti et al., 2014; Singh et al., 2018; Wałaszek et al., 2018; Zhang et al., 2020). The VOC- $\mathrm{NO}_{x}-\mathrm{O}_{3}$ 
chemistry at the ground level atmosphere is well understood (e.g., Atkinson, 2000; Crutzen, 1974; Seinfeld \& Pandis, 2016). $\mathrm{NO}_{\mathrm{x}}$ and VOC are primary species that originate from natural and anthropogenic sources such as vehicular traffic and industrial fossil fuel burning, and through episodic events like biomass burning and volcanoes (e.g., Barletta et al., 2002; Khillare et al., 2005, 2008a, 2008b; Hoque et al., 2008; Li et al., 2017; Ling et al., 2014; Sillman, 1999; Srivastava et al., 2006; Steinbrecher et al., 2009). Ozone is formed through the photolysis of $\mathrm{NO}_{2}$ and has a comparatively short lifetime in the air. However, its precursors can remain in the atmosphere for many days continuously forming ozone and resulting in long-range (often transboundary) transport (Wild et al., 2004; Young et al., 2013). Photochemical ozone production also occurs in rural and remote locations and in remote unpolluted areas (Crutzen, 1974).

Surface $\mathrm{O}_{3}$ shows explicit diel and seasonal variations, which are governed by the photochemistry of its production and removal (Debaje et al., 2003; Lal et al., 2000; Zhao et al., 2021). Highly reactive hydroxyl $\left({ }^{\circ} \mathrm{OH}\right)$ and nitrate $\left(\mathrm{NO}_{3}{ }^{\circ}\right)$ radicals are the important oxidative species in the troposphere during day and night, respectively. They are formed through reactions of $\mathrm{O}_{3}$ (e.g., Aschmann et al., 2002; Atkinson et al., 1995). The ${ }^{\bullet} \mathrm{OH}$ radical is the key species which initiates reactions of hydrocarbons ( $\mathrm{HC}$ ) and $\mathrm{CO}$ during the day, and in the process highly oxidizing peroxy radicals like $\mathrm{HOO}^{\bullet}$, alkyl peroxy radical $\left(\mathrm{ROO}^{\bullet}\right)$, and acyl peroxy radical $\left(\mathrm{RC}(\mathrm{O}) \mathrm{OO}^{\bullet}\right)$ are formed. These peroxy radicals compete with $\mathrm{O}_{3}$ to oxidize $\mathrm{NO}$ to $\mathrm{NO}_{2}$ leading to a situation where more $\mathrm{O}_{3}$ is formed than is consumed. This process leads to the built up of $\mathrm{O}_{3}$ during the day.

Two discrete regimes govern the ground level atmospheric ozone: (i) $\mathrm{NO}_{\mathrm{x}}$-sensitive regime, when the production of $\mathrm{O}_{3}$ is sensitive to the concentration of $\mathrm{NO}_{\mathrm{x}}$, and (ii) VOC-sensitive regime, when the increase in the concentration of $\mathrm{O}_{3}$ is a function of the concentration of VOC (Sillman, 1995; Finlayson-Pitts, 1999; Seinfeld \& Pandis, 2016). If controls are applied to the wrong precursor, the $\mathrm{O}_{3}$ concentrations can rise as has been seen in many places around the world since the COVID-19 pandemic led to substantial reductions in NO emissions in VOC-limited regions (e.g., Sicard et al., 2020; Sulaymon et al., 2021; Torkmahalleh et al., 2021).
Ground level atmospheric $\mathrm{O}_{3}$ also affects carbon dynamics, ecological interconnections, and agricultural efficiency across the ecosphere (Schneider et al., 2017). High $\mathrm{O}_{3}$ levels can lead to the closure of stomata, thereby reducing the uptake of gases affecting photosynthesis (Karnosky et al., 2003). Later, Ghude et al. (2014) reported reductions of crop yield in India due to surface ozone and, therefore, an agricultural economy like India's cannot ignore $\mathrm{O}_{3}$ pollution.

Surface ozone is also an important greenhouse gas contributing to global warming and climate change (IPCC, 2013; Kulkarni et al., 2011; Zhao et al., 2020). The concentration of $\mathrm{O}_{3}$ is changing in the global scale leading to an increase in the background concentrations, which influence the levels of local concentrations of $\mathrm{O}_{3}$ and $\mathrm{NO}_{2}$ (Clapp \& Jenkin, 2001). There are reports of reduction of particulate pollution but $\mathrm{O}_{3}$ remained constant or increasing, indicating the complexities in the $\mathrm{O}_{3}$ pollution and, therefore, its control (e.g., Squizzato et al., 2018).

Ozone in the lower atmosphere is termed as "bad" $\mathrm{O}_{3}$ for its adverse effects on human health and the environment. It was termed as lung irritant soon after its discovery (Bates, 1989). Health effects of increased concentration of $\mathrm{O}_{3}$ include reduction of lung functions, increased respiratory problems, and inflammation. Long-term exposure of $\mathrm{O}_{3}$ ultimately leads to chronic damage of the lungs in vertebrates (Lippmann, 1991). Ozone exposure can decrease the variability in heart rate of human beings thereby deteriorating the cardiac autonomic nervous system (Jia et al., 2011). The cardiovascular effects of ambient $\mathrm{O}_{3}$ are found in animals, when exposed for a long duration, thereby altering their vascular tone (Chuang et al., 2009; Paffett et al., 2015; Robertson et al., 2013).

There has been limited literature addressing $\mathrm{O}_{3}$ from India. More so, the reported studies are generally from major metropolitan areas, at sites that are often heavily influenced by local sources like traffic (e.g., Badarinath et al., 2009a, 2009b; Beig et al., 2013; Ganguly \& Tzanis, 2013; Lal et al., 2012; Singla et al., 2011). There are a few studies on the ground level atmospheric $\mathrm{O}_{3}$ from the Brahmaputra Valley region (e.g., Bharali et al., 2015; Bhuyan et al., 2014; Dumka et al., 2020; Pathak et al., 2016). Tyagi et al. (2020) examined the $\mathrm{O}_{3}$ concentrations of three stations in northeastern India (including Tezpur) as well as surface temperatures and other meteorological 
parameters. They concluded that there is significant transport of $\mathrm{O}_{3}$ to the region; however, they did not address the air mass trajectory pathways/regions that contributed to higher $\mathrm{O}_{3}$.

Therefore, this study was taken up to determine the variability of ground level $\mathrm{O}_{3}$ on a daily and seasonal basis in a relatively rural area of the mid-Brahmaputra Valley. Ozone has been assessed in terms of the $\mathrm{NO}_{\mathrm{x}}-\mathrm{O}_{3}$ photostationary state to understand the processes that are driving the $\mathrm{O}_{3}$ concentration. Concentration-weighted trajectory (CWT) analysis was done to identify likely source regions from where air masses carrying precursors originated and were subsequently transported to the region contributing to the formation of $\mathrm{O}_{3}$.

\section{Methodology}

The site

Ozone, $\mathrm{NO}$ and $\mathrm{NO}_{2}$, and meteorological variables were measured on the Tezpur University campus $\left(26^{\circ}\right.$ $37^{\prime} \mathrm{N}$ and $92^{\circ} 50^{\prime} \mathrm{E}$ ) under the MAPAN (monitoring of atmospheric pollution and networking) program. The location of the study area along with illustrative air mass back trajectories during winter is shown in Supplemental Fig. S1. The diel patterns' atmospheric temperature through the year over the study area is shown in Fig. S2. The site is characterized as a rural residential/institutional area. The station is surrounded by villages and agricultural fields. Tezpur city had a population of about 2.0 million (Census of India, 2011). The moderately busy highways are at about $20 \mathrm{~km}$ and the eastern Himalayan ranges begin at $30 \mathrm{~km}$ on the north from the monitoring station. The region is still developing. Traditional biomass burning in homes, agriculture, and forest are seen in the surrounding areas of the study site previously reported by Bhuyan et al. (2018).

\section{Methodology}

Continuous hourly measurements of $\mathrm{O}_{3}, \mathrm{NO}$, and $\mathrm{NO}_{2}$ and meteorological parameters for two consecutive years (2013-14 and 2014-15) were used for the study. The $\mathrm{O}_{3}$ measurements were made with a Serinus 10 ozone analyzer (Ecotech). This analyzer uses non-dispersive ultraviolet (UV) absorption technology to measure $\mathrm{O}_{3}$ with a sensitivity of $0.5 \mathrm{ppb}$ and in the range of 0-20 ppm (Ecotech user manual, 2010; Dumka et al., 2020). The measurements of NO and $\mathrm{NO}_{2}$ were made with a Serinus 40 Oxides of Nitrogen analyzer (Ecotech) that uses gas phase chemiluminescence detection. The concentration of $\mathrm{NO}_{\mathrm{x}}$ is the sum of the concentrations of $\mathrm{NO}$ and $\mathrm{NO}_{2}$. This Serinus 40 analyzer measures with a sensitivity of $0.4 \mathrm{ppb}$ with auto ranging of 0-20 ppm (Ecotech, 2011; Gilge, 2010; Yadav et al., 2014). Another important parameter estimated in this study was total oxidant $\left(\mathrm{OX}=\mathrm{O}_{3}+\mathrm{NO}_{2}\right)$ that assists in understanding the $\mathrm{O}_{3}$ behavior. Hourly average measurements of meteorological variables were made at the same station. The four seasons considered in the study were as per the India Meteorological Department (Laskar et al., 2016.): pre-monsoon (March-May), monsoon (June-September), post-monsoon (October-December), and winter (January-February).

The R package, Openair (Carslaw, 2018; Carslaw $\&$ Ropkins, 2012) was used for analyses and illustrations and in computing the polar plots. The air mass back trajectories were computed using TrajStat software that applies NOAA/ARL HYSPLIT (Hybrid Single-Particle Lagrangian Integrated Trajectory) model to calculate back trajectories. The NCEP/NCAR Reanalysis data (ftp://arlftp.arlhq. noaa.gov/pub/archives/reanalysis) were used to compute $72 \mathrm{~h}$ (3 days) back trajectories arriving at the site every hour (Draxler \& Hess, 1998; Rolph et al., 2017; Stein et al., 2015). The time difference between UTC and local time was carefully adjusted so that the time of the measurement of concentration and the time of reaching the trajectory matched.

Concentration-weighted trajectory (CWT) analysis was applied where trajectories were weighted with associated concentrations. Each grid was assigned a residence-time-weighted concentration from the measured data associated with the trajectories that crossed that grid cell, as follows:

$C_{i j}=\frac{1}{\sum_{l=1}^{M} \tau i j l} \sum_{l=1}^{M} c_{l} \tau_{i j l}$

where,

$C_{i j}$ - average weighted concentration in the $i j$ th cell.

$l$ - index of the trajectory. 
$M$ - total number of trajectories.

$C_{l}$ - concentration observed on arrival of trajectory $l$.

cijl - time spent in the $i j$ th cell by trajectory $l$.

In the cases of higher $C_{i j}$, it could be inferred that air masses that passed over the $i j$ th cell were transporting that species leading to high concentrations at the receptor site. To reduce the effect of a small number of polluted trajectories, a weighting function was multiplied with the CWT (Wang et al., 2009).

\section{Results and discussion}

\section{Concentrations}

The concentrations of hourly $\mathrm{O}_{3}$, maximum $\mathrm{O}_{3}$ of the day $\left(\mathrm{O}_{3} \max \right), \mathrm{NO}, \mathrm{NO}_{2}, \mathrm{NO}_{\mathrm{x}}$, and $\mathrm{OX}$ for the years 2013-14 and 2014-15 are shown in Fig. 1, and the descriptive statistics are given in Table S1. The 95th percentile $\mathrm{O}_{3}$ concentrations were $43 \mathrm{ppb}$ during 2013-2014 and 41 ppb during 2014-2015. The minimum concentration was $1 \mathrm{ppb}$ during both the years. The 95th percentile $\mathrm{NO}_{\mathrm{x}}$ concentrations were $15 \mathrm{ppb}$ during 2013-2014 and 14 ppb during 2014-2015. Low $\mathrm{NO}_{x}$ and comparatively high $\mathrm{O}_{3}$ are typical of remote locations where the production of $\mathrm{O}_{3}$ is mainly governed by the $\mathrm{NO}_{\mathrm{x}}$ concentration (Chameides et al., 1992). However, in a high $\mathrm{NO}_{\mathrm{x}}$ regime like

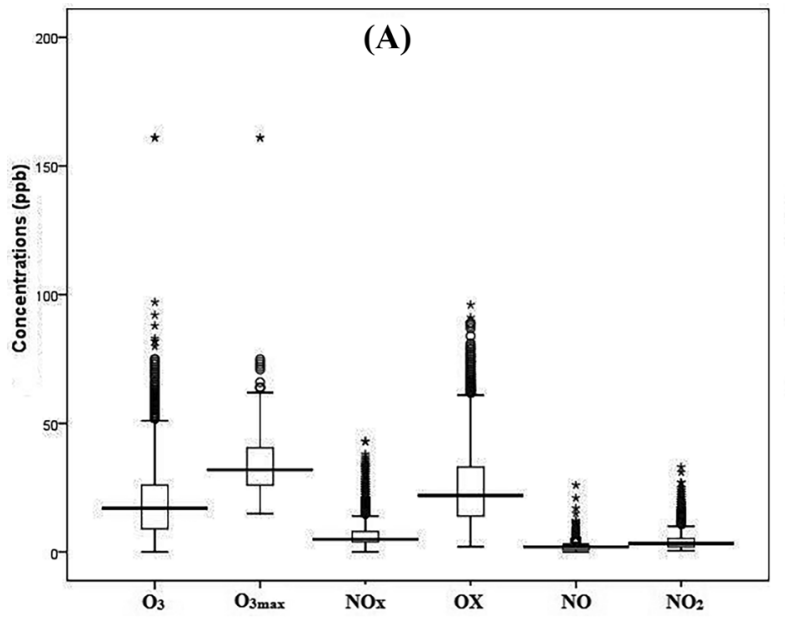

Fig. 1 Box plot of measured concentrations for the years (a) 2013-2014 and (b) 2014-2015. The central solid lines inside the box represent median values of the respective species; the an urban area, the production of $\mathrm{O}_{3}$ is controlled by $\mathrm{NO}_{\mathrm{x}}$ and VOC levels (Chameides et al., 1992; Sillman et al., 1990).

A summary of $\mathrm{O}_{3}$ concentrations from the present study and related studies is provided in Table 1 . Bhuyan et al. (2014) reported a maximum $\mathrm{O}_{3}$ concentration of $43 \mathrm{ppb}$ from urban Dibrugarh in the upper Brahmaputra Valley that was comparable to the present study values. Tezpur experienced higher maximum concentrations of $\mathrm{O}_{3}$ compared to several regions of the Indian mainland, e.g., uplands of Udaipur (28 ppb; Yadav et al., 2014), city area of Ahmedabad (30 ppb; Lal et al., 2000), Coastal Tranquebar (37 ppb; Debaje et al., 2003), and semiurban areas of Jodhpur (22 ppb; Pancholi et al., 2018). There are several reports of higher maximum concentrations of $\mathrm{O}_{3}$ compared to the present study form the mainland India (e.g., urban areas of Pune; 5 ppb; Beig et al., 2007), urban commercial areas of Agra (72 ppb; Satsangi et al., 2004), semi-arid rural continental location of Anantapur (72 ppb; Reddy et al., 2012), and urban high-altitude area of Ooty (62 ppb; Udayasoorian et al., 2013). There were reports where the $\mathrm{O}_{3}$ values were comparable to those in Tezpur. These locations include a rural mountain valley of Kannur (44 ppb; Nishanth et al., 2012), a busy urban industrial area of Lahore (41 ppb; Tabinda et al., 2016). Sarangi et al. (2014) reported average monthly $\mathrm{O}_{3}$ concentrations in a remote high-altitude location of central Himalayas (Nainital, India) where concentrations were in the upper

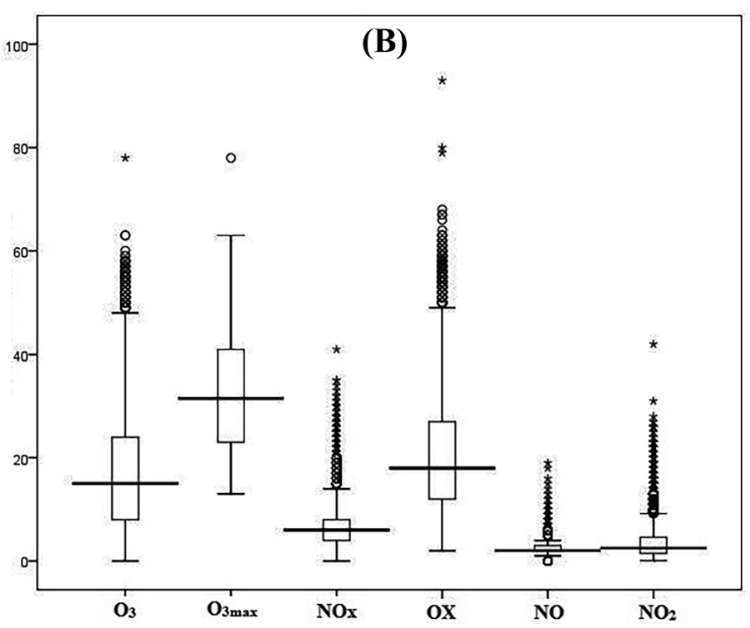

whiskers are maximum (95th percentile) and minimum values excluding the outliers 
Table.1 Comparison of ground level atmospheric ozone concentrations over mid Brahmaputra Valley region with concentrations reported elsewhere

\begin{tabular}{|c|c|c|c|c|}
\hline Location & Land use & $\mathrm{Max}_{3}$ & $\operatorname{Min} \mathrm{O}_{3}$ & Reference \\
\hline $\begin{array}{l}\text { Tezpur, India (2013- } \\
\text { 2014) }\end{array}$ & Rural & 43 ppb* & $1 \mathrm{ppl}$ & Present study \\
\hline $\begin{array}{l}\text { Tezpur, India (2014- } \\
\text { 2015) }\end{array}$ & Rural & 41 ppb. $*$ & $1 \mathrm{ppb}$ & Present study \\
\hline Anantapur, India & $\begin{array}{l}\text { Semi-arid rural, } \\
\text { continental region }\end{array}$ & $\begin{array}{l}70.2 \pm 6.9 \mathrm{ppbv} \\
\text { (summer) }\end{array}$ & $\begin{array}{l}20.0 \pm 4.7 \mathrm{ppbv} \\
\text { (monsoon) }\end{array}$ & Reddy et al., (2012) \\
\hline Kannur, India & $\begin{array}{l}\text { Rural, valley of } \\
\text { mountains }\end{array}$ & 44 ppbv (winter) & 18.5 ppbv (monsoon) & Nishanth et al., (2012) \\
\hline Udaipur, India & Urban, hill range & 28 ppbv (pre-monsoon) & 19 ppbv (monsoon) & Yadav et al., (2014) \\
\hline Dibrugarh, India & $\begin{array}{l}\text { Urban, upper } \\
\text { Brahmaputra basin }\end{array}$ & $42.9 \pm 10.3 \mathrm{ppb}($ March $)$ & $17.3 \pm 7.0$ ppb (July) & Bhuyan et al., (2014) \\
\hline Ahmedabad, India & Urban, Industrial area & $30 \pm 3$ ppbv (November) & $12 \pm 2$ ppbv (Aug) & Lal et al., (2000) \\
\hline Ooty, India & $\begin{array}{l}\text { Urban, high altitude } \\
\text { western ghats }\end{array}$ & $62 \mathrm{ppb}$ (March) & 17 ppb (Aug) & $\begin{array}{l}\text { Udayasoorian et al., } \\
\text { (2013) }\end{array}$ \\
\hline Jodhpur, Rajasthan & Urban, semi-arid desert & $21.9 \mathrm{ppb}$ (pre-monsoon) & 12.6 ppb (monsoon) & Pancholi et al., (2018) \\
\hline Agra, India & $\begin{array}{l}\text { Urban, semi-arid } \\
\text { commercial zone }\end{array}$ & $72.3 \mathrm{ppb}$ (November) & $2.2 \mathrm{ppb}$ (February) & Satsangi et al., (2004) \\
\hline Tranquebar, India & Urban, coastal region & 37 ppbv (May) & 9 ppbv (October) & Debaje et al., (2003) \\
\hline Pune, India & $\begin{array}{l}\text { Semi-urban, industrial } \\
\text { site }\end{array}$ & 54.6 ppbv (February) & 12.2 ppbv (August) & Beig et al., (2007) \\
\hline Oki, Japan & $\begin{array}{l}\text { Rural, small remote } \\
\text { island }\end{array}$ & $55 \mathrm{ppb}$ (spring) & 29 ppb (summer) & Pochanart et al., (1999) \\
\hline Istanbul, Turkey & Urban, industrial area & $32 \mathrm{ppb}$ (summer) & $8 \mathrm{ppb}$ (winter) & Im et al., (2013) \\
\hline $\begin{array}{l}\text { Meadowlands, New } \\
\text { Jersey }\end{array}$ & $\begin{array}{l}\text { Urban, heavily } \\
\text { industrialized }\end{array}$ & 63 ppb (June) & $0.2 \mathrm{ppb}$ (November) & $\begin{array}{l}\text { Roberts-Semple et al., } \\
\text { (2012) }\end{array}$ \\
\hline Namibia, Africa & Urban, high altitude & 30 ppb (October) & $11 \mathrm{ppb}$ (March) & Zunckel et al., (2004) \\
\hline Dhaka, Bangladesh & $\begin{array}{l}\text { Urban, highly traffic } \\
\text { congested }\end{array}$ & 97 ppb (Winter) & 16 ppb (monsoon) & Sikder et al., (2013) \\
\hline Nepal & Urban, high altitude & $\begin{array}{l}60.9 \text { ppbv (pre- } \\
\text { monsoon) }\end{array}$ & 38.9 ppbv (monsoon) & Bonasoni et al., (2010) \\
\hline Lahore, Pakistan & $\begin{array}{l}\text { Urban, busiest town, } \\
\text { industrial area }\end{array}$ & 41.36 ppb (June) & 5.27 ppb (January) & Tabinda et al., (2016) \\
\hline Barcelona, Spain & Urban, highly populated & $24.51 \mathrm{ppb}$ (June) & $4.15 \mathrm{ppb}$ (December) & $\begin{array}{l}\text { Filella \& Penuelas, } \\
\text { (2006) }\end{array}$ \\
\hline Giza, Cairo & Urban, industrial site & 143 ppb (July) & 50 ppb (January) & Khoder, (2009) \\
\hline Marikana, South Africa & Urban, township & $50.02 \mathrm{ppb}$ (October) & 21.07 ppb (April) & Kgabi \& Sehloho, (2012) \\
\hline Mohal-Kullu, India & Semi-rural & $\begin{array}{l}74.6 \pm 23.2 \mathrm{ppb} \\
\quad \text { (summer) }\end{array}$ & $\begin{array}{l}16.0 \pm 5.6 \mathrm{ppb} \\
(\text { monsoon })\end{array}$ & Kuniyal et al., (2021) \\
\hline Telengana, India & Sub-urban & $\begin{array}{l}35.54 \pm 7.16 \mathrm{ppbv} \\
\quad \text { (winter) }\end{array}$ & $\begin{array}{l}12.70 \pm 3.55 \mathrm{ppbv} \\
\text { (monsoon) }\end{array}$ & Kanchana et al., (2020) \\
\hline
\end{tabular}

*95th percentile concentration

range of values observed in the mid-Brahmaputra Valley. The proximity of Nainital to one of the most polluted regions of India, the Indo-Gangetic Plain (IGP) could have resulted in higher $\mathrm{O}_{3}$ values in the hills. In another study from the Nepalese Himalayas, a maximum
$\mathrm{O}_{3}$ concentration of $60 \mathrm{ppb}$ was reported that could have been an outcome of the valley effect. In neighboring Bangladesh, Sikder et al. (2013) reported a high maximum $\mathrm{O}_{3}$ concentration of $97 \mathrm{ppb}$ in Dhaka. Therefore, it appears that the maximum ozone concentrations 
varied in different locations likely related to the land uses. Although the station at Tezpur is a rural location, the maximum $\mathrm{O}_{3}$ values were on higher compared to other similar locations of Indian subcontinent.

Diel and seasonal variations of $\mathrm{O}_{3}$

The hour of the week of $\mathrm{O}_{3}$ concentrations in the year 2014 (January to December)) are shown in Fig. 2A. The hour of the week plot generally showed $\mathrm{O}_{3}$ trends with single peak (maximum ozone) during the afternoons. The diel pattern of $\mathrm{O}_{3}$ in 2014 is shown in Fig. 2B that shows a clear afternoon peak. This pattern is different from the trends of urban areas where the maximum ozone is experienced at midday (e.g., Dumka et al., 2020; Han et al., 2011; Reddy et al.,
2012; Yadav et al., 2014). The diel $\mathrm{O}_{3}$ concentration variation followed the progression of temperature during the day shown in Fig. S2. Increased $\mathrm{O}_{3}$ concentrations have been reported to follow the increase in atmospheric temperature (AT) (e.g., Coates et al., 2016). Temperature affects the $\mathrm{O}_{3}$ formation by speeding up the rates of chemical reactions, e.g., $\mathrm{O}_{3}+\mathrm{NO}+h v \rightarrow \mathrm{NO}_{2}+\mathrm{O}$ is a function of temperature, which is the reaction that leads to the formation of $\mathrm{O}_{3}$ by reaction with $\mathrm{O}_{2}$. AT also increases the rate of emission of biogenic VOCs (Sillman \& Samson, 1995) as well as the evaporative emission of VOCs (Rubin et al., 2006).

The $\mathrm{O}_{3}$ distributions across the days of the week (Fig. 2C) showed a small rise in the concentrations during Monday, Thursday, and Friday with the

(A)

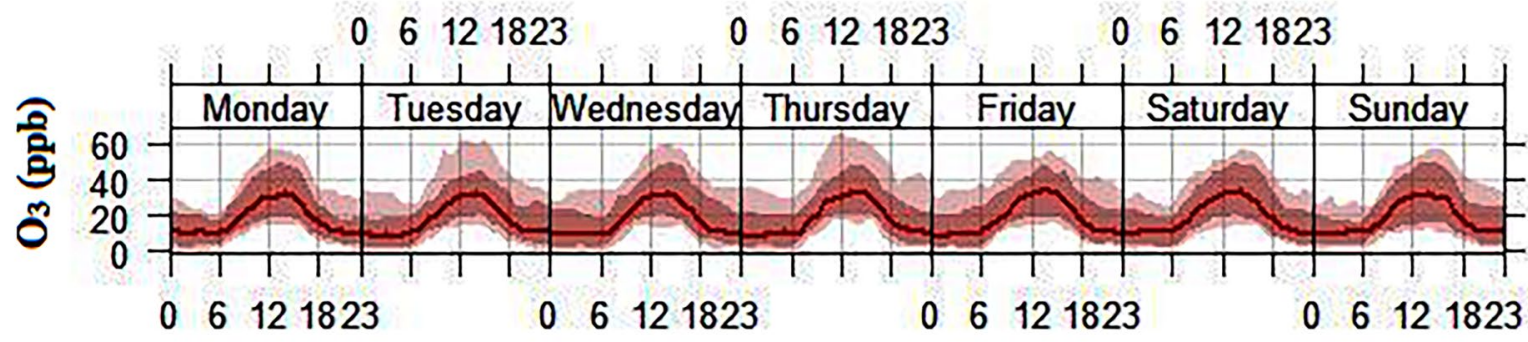

hour

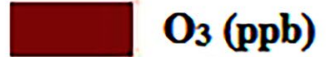

(B)

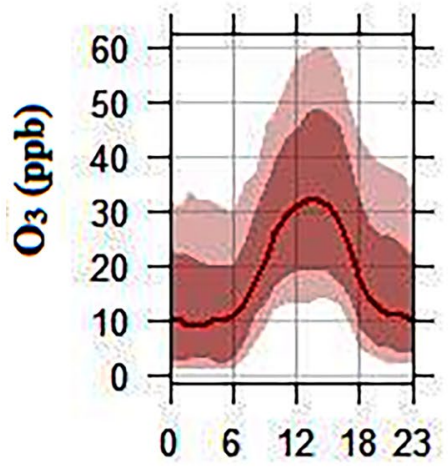

hour
(C)

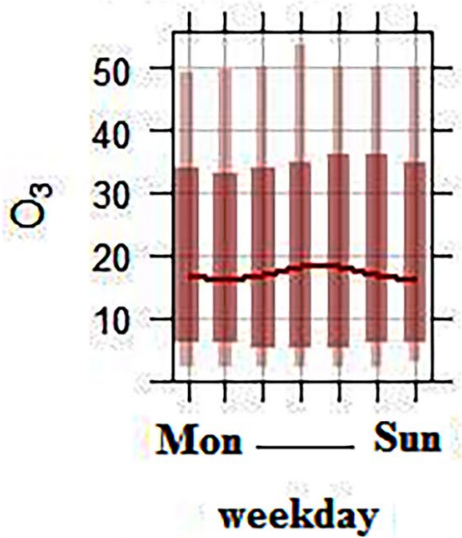

(D)

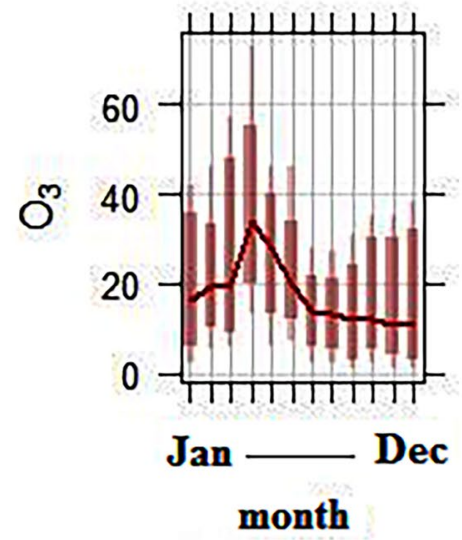

Fig. 2 Variations in the concentrations of $\mathrm{O}_{3}$ (mean $\mathrm{O}_{3}$ and 95\% confidence interval in mean): (a) variations in the hourly mean concentrations of $\mathrm{O}_{3}$ as the days progressed in a week of the year (Monday to Sunday); (b) variations of hourly mean concentrations of $\mathrm{O}_{3}$ as the day of the year progressed; (C) concentrations of mean $\mathrm{O}_{3}$ in weekdays (Monday to Sunday); and (d) monthly variations of mean $\mathrm{O}_{3}$ concentrations (January to December, 2014) 
concentrations decreasing only marginally on Tuesday, Wednesday, and during the weekends. Higher $\mathrm{O}_{3}$ is observed on weekends due to reduction of $\mathrm{NO}_{\mathrm{x}}$ emissions on weekends in a VOC-limited regime (Cleveland et al., 1974; Sicard et al., 2020; Wolff et al., 2013). The occurrence of higher levels of $\mathrm{O}_{3}$ is termed as the "weekend effect." The ${ }^{\bullet} \mathrm{OH}$ radical initiated reactions of VOC play a key role here and a significant lowering of $\mathrm{NO}_{\mathrm{x}}$ makes more ${ }^{\circ} \mathrm{OH}$ available to initiate the oxidation of VOCs leading to an increase in the ozone formation (Fujita et al., 2003). Also, the lack of titration of $\mathrm{O}_{3}$ and the ability of the peroxides and peroxy radicals to cycle the $\mathrm{NO}$ more rapidly to the $\mathrm{NO}_{2}$ to be photolyzed allows the formation of additional $\mathrm{O}_{3}$. Alternatively, lower weekend $\mathrm{O}_{3}$ concentrations could be the result of $\mathrm{NO}_{\mathrm{x}}$ reduction in a $\mathrm{NO}_{\mathrm{x}}$-limited regime.

The month-to-month $\mathrm{O}_{3}$ pattern in 2014 is shown in Fig. 2D. It clearly shows pre-monsoon (April) $\mathrm{O}_{3}$ concentrations maxima at this site (e.g., Crutzen, 1988; Dumka et al., 2020; Gilge et al., 2010; Yadav et al., 2014). The monthly average AT in the study area has been presented in Fig. S2(b). The maximum average monthly AT across the study region was seen during July-August. However, the ozone maxima were found during April when the temperatures were warm (20 to $30{ }^{\circ} \mathrm{C}$ ) and enhanced photochemical reactions. Although AT has a role in increasing the $\mathrm{O}_{3}$ formation through increasing the rate constants for important reaction, temperature also enhances the rates of biogenic emission of VOCs (e.g., Coates et al., 2016; Gu et al., 2020; Rubin et al., 2006; Sillman \& Samson, 1995). The time series plots of the concentrations of $\mathrm{O}_{3}, \mathrm{NO}_{\mathrm{x}}, \mathrm{NO}_{2}$, and $\mathrm{NO}$ of the study period are given in Fig. S3. The pre-monsoon maximum of $\mathrm{O}_{3}$ is clearly seen in these plots. However, maximum $\mathrm{NO}_{\mathrm{x}}$ concentration was observed in the winter months. The meteorological conditions during the pre-monsoon favored the rise of $\mathrm{O}_{3}$ concentration. The maximum concentration of $\mathrm{O}_{3}$ was seen in the month of April when plants start growing strongly and emit more reactive VOCs. In this region, March-April are the main foliating months in the forests and tea plantations, which would lead to elevated emission of biogenic VOCs (BVOC) and impacting the $\mathrm{O}_{3}$ formation (e.g., Wu et al., 2020). Also, there are controlled burning fires in the forests for management (Badarinath et al., 2009a). These fires emit large quantities of reactive organic compounds that also interact with the $\mathrm{NO}_{\mathrm{x}}$ chemistry and $\mathrm{O}_{3}$ formation (Singh et al., 1995). Previously, Tyagi et al. (2020) examined $\mathrm{O}_{3}$ with respect to AT of three stations in the northeastern India and did not find a dependency of $\mathrm{O}_{3}$ on temperature. They inferred this discrepancy to the transport of $\mathrm{O}_{3}$ into the region. However, the role of VOCs of both biogenic and anthropogenic origins cannot be overlooked in the present study.

Diel patterns of $\mathrm{O}_{3}$ and $\mathrm{O}_{3}-\mathrm{NO}_{\mathrm{x}}$ photostationary state

The $\mathrm{O}_{3}-\mathrm{NO}_{\mathrm{x}}$ relationship can be explained by the following reactions after Leighton (1961):

$$
\begin{aligned}
& \mathrm{NO}_{2} h v\left(<424^{\circ} \mathrm{nm}\right) \stackrel{J_{1}}{\rightarrow} \mathrm{NO}+\mathrm{O} \\
& \mathrm{O}+\mathrm{O}_{2}+\mathrm{M} \stackrel{\mathrm{k}_{2}}{\rightarrow} \mathrm{O}_{3}+\mathrm{M} \\
& \mathrm{O}_{3}+\mathrm{NO}+h v \stackrel{k_{3}}{\rightarrow} \mathrm{NO}_{2}+\mathrm{O}
\end{aligned}
$$

Daytime $\mathrm{O}_{3}, \mathrm{NO}_{2}$, and $\mathrm{NO}$ equilibrate on a timescale of a few minutes (Clapp \& Jenkin, 2001) to reach a "dynamic" equilibrium called the "photostationary state" (PS), wherein $d\left[\mathrm{O}_{3}\right] / d t=0$ (Seinfeld \& Pandis, 2016). If $J_{1}$ is the rate of the photodissociation of $\mathrm{NO}_{2}$ including the light intensity (Eq. 2) and $k_{3}$ is the rate coefficient of the formation of $\mathrm{NO}_{2}$ (Eq. 4), then the $P S$ can be explained by the ratio $J_{1} / k_{3}=\left[\mathrm{O}_{3}\right]$ $[\mathrm{NO}] /\left[\mathrm{NO}_{2}\right]$, which will govern the concentrations of $\mathrm{O}_{3}, \mathrm{NO}_{2}$, and $\mathrm{NO}$ during the day. $J_{1}$ is a function of solar intensity so it includes a diel variability whereas $k_{3}$ is a function of temperature. The $k_{3}$ varies with temperature as given by Seinfeld and Pandis (2016):

$k_{3}\left(p m^{-1} \mathrm{~min}^{-1}\right)=3.23 \times 10^{3} \exp [-1430 / T]$

However, the accumulation of $\mathrm{O}_{3}$ in the lower atmosphere is more complicated, and reactions that convert $\mathrm{NO}$ to $\mathrm{NO}_{2}$ with no-or-less destruction of $\mathrm{O}_{3}$ are required for $\mathrm{O}_{3}$ to accumulate. Ozone reacts with olefins to form Criegee intermediates that can decompose to produce ${ }^{\bullet} \mathrm{OH}$ and peroxy radicals. The ${ }^{\bullet} \mathrm{OH}$ radicals oxidize other VOCs and $\mathrm{CO}$ to form additional oxidizing radicals like $\mathrm{HOO}^{\bullet}$ and $\mathrm{ROO}^{\bullet}$. These oxidants convert $\mathrm{NO}$ to $\mathrm{NO}_{2}$ without the destruction of and $\mathrm{O}_{3}$ (Eq. 4) as outlined in (Eq. 6) to (Eq. 11) (Atkinson, 2000; Greiner, 1967; Stedman et al., 1970):

$\mathrm{RH}+\mathrm{OH} \rightarrow \mathrm{R}+\mathrm{H}_{2} \mathrm{O}$ 
$\mathrm{R}+\mathrm{O}_{2} \rightarrow \mathrm{ROO}$

$\mathrm{ROO}+\mathrm{NO} \rightarrow \mathrm{RO}^{\circ}+\mathrm{NO}_{2}$

$\mathrm{CO}+\mathrm{OH} \rightarrow \mathrm{CO}_{2}+\mathrm{H}$

$\mathrm{H}+\mathrm{O}_{2} \rightarrow \mathrm{HOO}$

$\mathrm{HOO}+\mathrm{NO} \rightarrow \mathrm{OH}+\mathrm{NO}_{2}$

There are external factors that can affect the $P S$ including transport of $\mathrm{O}_{3}$, the nature and concentrations of VOCs, alternate generation of peroxy radicals such as photolysis of short-chin carbonyls, and local sources and transport of $\mathrm{NO}_{\mathrm{x}}$ (Khalil, 2018). Due to these complexities, a "true" $P S$ is rarely attained in the ground level atmosphere.

Thus, the net $\mathrm{O}_{3}$ (measured $\mathrm{O}_{3}$ concentration) and $J_{1} / k_{3}$ were plotted against time of day for the different seasons to ascertain how the temporal variation of $\mathrm{O}_{3}$ behaved relative to $J_{1} / k_{3}$ (Fig. 3). The net $\mathrm{O}_{3}$ and $J_{1} / k_{3}$ attained a maximum during midday to the early afternoon hours, and then both parameters declined as the day progressed.

During the pre-monsoon and monsoon seasons (Fig. 3a, b), the net $\mathrm{O}_{3}$ and $J_{1} / k_{3}$ attained their maxima and were about equal during midday to afternoon (1130 $\mathrm{h}$ to $1530 \mathrm{~h}$ local time). In this period, much of the $\mathrm{NO}_{2}$ has photolyzed to give $\mathrm{O}_{3}$, and the net $\mathrm{O}_{3}$ was a function of $\mathrm{NO}_{\mathrm{x}}$. These two seasons are much warmer seasons compared to the post-monsoon and winter periods, and the days are longer. Maximum sunshine and temperature occur during that time period (1130 h to $1530 \mathrm{~h}$ ). It was also interesting to see that the maxima were attained long after the sunrise, which is the high traffic period of the morning hours.

During post-monsoon and winter seasons (Fig. 3c, d), the net $\mathrm{O}_{3}$ and $J_{1} / k_{3}$ peaked for a shorter duration
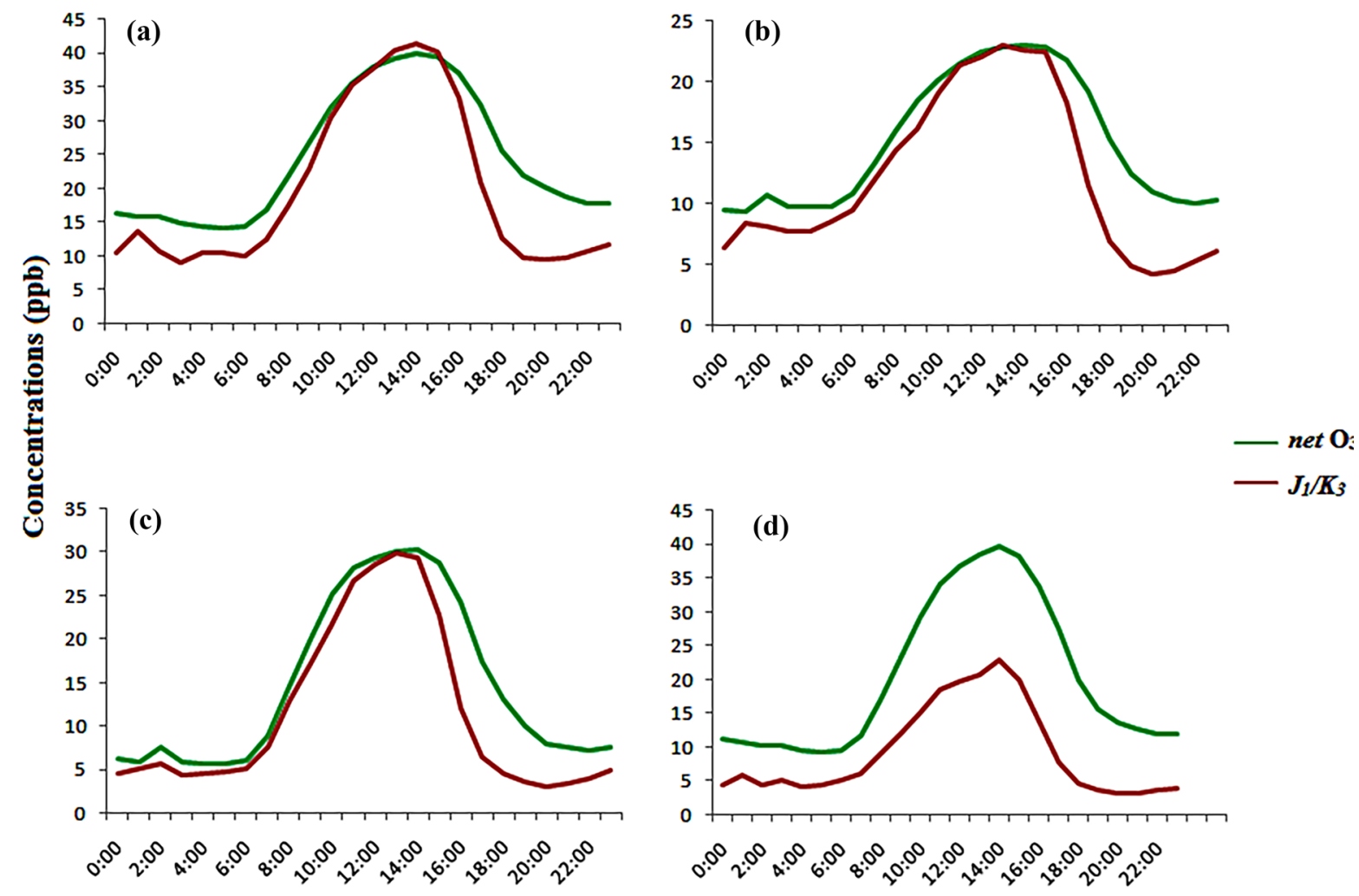

Time

Fig. 3 net $\mathrm{O}_{3}$ (measured concentrations) and $J_{1} / k_{3}$ plotted against time of the day in different seasons: (a) pre-monsoon, (b) monsoon, and (c) post-monsoon, (d) winter. 
at around 14:00 local time. During the post-monsoon net $\mathrm{O}_{3}$ and $J_{1} / k_{3}$ were nearly equal at $\sim 1400 \mathrm{~h}$ local time. However, during the winter, net $\mathrm{O}_{3}$ and $J_{1} / k_{3}$ never became equal. During the peak hour, the levels of net $\mathrm{O}_{3}$ were much higher than the $J_{1} / k_{3}$ during the winter month.

During all the seasons, the ratio $\left(J_{1} / k_{3}\right)$ and net $\mathrm{O}_{3}$ fell after the peak. The slopes of net $\mathrm{O}_{3}$ and $J_{1} / k_{3}$ were not similar. The fall in the case of $J_{1} / k_{3}$ was much sharper than net $\mathrm{O}_{3}$ and the levels of net $\mathrm{O}_{3}$ remained higher than the ratio during the rest of the day. Also, net $\mathrm{O}_{3}$ was found to be higher than $J_{1} / k_{3}$ during the period preceding the peak period. During the winter season, the net $\mathrm{O}_{3}$ was always much higher than $J_{1} / k_{3}$ This discrepancy points at the factors that cause deviations of net $\mathrm{O}_{3}$ from the $P S$. Those factors include transport of $\mathrm{O}_{3}$ and the role of VOCs. The activity of VOC and involvement of $\mathrm{OH}$ are local (Khalil, 2018), and $\mathrm{OH}$ generation and reactions of VOC degradation and production of $\mathrm{O}_{3}$ in the process happens in situ. However, the VOCs and $\mathrm{NO}_{\mathrm{x}}$ could be from both local emission and long-range transport.

The local sources of elevated levels of VOCs were biomass burning and biogenic emissions. The longrange transport of peroxyacyl nitrate (PAN) and other PAN homologues from the IGP can add $\mathrm{NO}_{\mathrm{x}}$ and radicals in the region during the winter, which are important drivers of $\mathrm{O}_{3}$ production.

Though biomass burning is prevalent in the region (Deka \& Hoque, 2015), during the winter months, there is escalation in the biomass burning which is a major source of VOCs in the atmosphere. A unique festive biomass burning, locally known as meji burning during mid-January each year is a major emitter of particulate matter and gases (Deka \& Hoque, 2014; Hoque \& Deka, 2010) that also have implications on the oxidative behavior of the regional atmosphere and $\mathrm{O}_{3}$ buildup in the winter period.

Biomass burning emits loads of oxygenated hydrocarbons like aldehydes, ketones, and alcohol which are important sources of free radicals linked with the reactivity of $\mathrm{NO}_{\mathrm{x}}$ and ozone formation. Acetone alone can provide a high production of $\mathrm{HO}_{\mathrm{x}}\left({ }^{\bullet} \mathrm{OH}\right.$ and $\mathrm{HOO}^{\circ}$ ) radicals thereby enhancing the production of $\mathrm{O}_{3}$ (Singh et al., 1995). The alcohols also further undergo oxidation giving rise more reactive aldehydes and radicals that would favor $\mathrm{O}_{3}$ formation explained by the following reaction (Singh et al., 1995):

$$
\begin{aligned}
& \mathrm{CH}_{3} \mathrm{OH}+\mathrm{OH}+\left(\mathrm{O}_{2}\right) \rightarrow \mathrm{CH}_{2} \mathrm{O}+\mathrm{HOO}+\mathrm{H}_{2} \mathrm{O} \\
& \mathrm{C}_{2} \mathrm{H}_{5} \mathrm{OH}+\mathrm{OH}+\left(\mathrm{O}_{2}\right) \rightarrow \mathrm{CH}_{3} \mathrm{CHO}+\mathrm{HOO}+\mathrm{H}_{2} \mathrm{O}
\end{aligned}
$$

Another important source of VOC in the winter months is agriculture. The whole of the Brahmaputra Valley region is widely cultivated with crops from the Brassicaceae family that are known to emit volatile organics (Gan et al., 1998; Mead et al., 2008). Rapeseed, cabbage, and radish are principal winter crops of the Brahmaputra Valley. There is a large area (0.276 million ha) under rapeseed cultivation (Das, 2015). Even the fallow lands are used for rapeseed since it is a hardy crop and does not need irrigation and excessive manuring. Similarly, large areas are under cabbage (33.24 kha) and radish (21.17 kha) (Horticulture Statistics Division, 2018). The Brassicaceae family is known to emit large volumes of $\mathrm{CH}_{3} \mathrm{Br}$ and other organics (Gan et al., 1998; Mead et al., 2008). $\mathrm{CH}_{3} \mathrm{Br}$ is a reactive gas and provides a source of radicals that covert $\mathrm{NO}$ to $\mathrm{NO}_{2}$ and enhance the production of $\mathrm{O}_{3}$ (Orlando et al., 1996), shown in Eqs. 14-16:

$\mathrm{CH}_{3} \mathrm{Br}+\mathrm{OH} \rightarrow \mathrm{CH}_{2} \mathrm{Br}+\mathrm{H}_{2} \mathrm{O}$

$\cdot \mathrm{CH}_{2} \mathrm{Br}+\mathrm{O}_{2}+\mathrm{M} \rightarrow \mathrm{CH}_{2} \mathrm{BrOO}+\mathrm{M}$

$\mathrm{CH}_{2} \mathrm{BrOO}+\mathrm{NO} \rightarrow \mathrm{CH}_{2} \mathrm{BrO}+\mathrm{NO}_{2}$

PAN is a source of $\mathrm{NO}_{\mathrm{x}}$ and organic radicals in the remote atmosphere. The thermochemical stability of PAN depends on the temperature and is quite stable at low temperature. At $7{ }^{\circ} \mathrm{C}$ and $\mathrm{NO}_{2} / \mathrm{NO}$ ratio of $2-20$, the lifetime of PAN ( $\tau_{\text {PAN }}$ ) is $\sim 19$ to $120 \mathrm{~h}$, and at $27{ }^{\circ} \mathrm{C}, \tau_{\text {PAN }}$ is $\sim 0.75 \mathrm{~h}$ to $4.4 \mathrm{~h}$ (Altshuller, 1993). Other PANs have similar lifetimes. Therefore, at low temperatures, PAN can be transported long-range and pump in $\mathrm{NO}_{\mathrm{x}}$ and organic radicals to the remote regions. Analysis of the air mass back trajectories reaching the site during winter (Fig. S1) suggests that $28 \%$ of the trajectories traveled from the IGP region of India. The IGP is one of the most polluted regions of India from where aided by the low temperatures, there was likely transport to the study area of PAN. As the trajectories reached the site where the temperature is $10{ }^{\circ} \mathrm{C}$ to $24^{\circ} \mathrm{C}$ in the winter, the PAN decomposed to $\mathrm{NO}_{\mathrm{x}}$ and organic radicals (Eq. 17): 


$$
\mathrm{CH}_{3} \mathrm{C}(\mathrm{O}) \mathrm{OONO}_{2}+\mathrm{M} \rightarrow \mathrm{CH}_{3} \mathrm{C}(\mathrm{O}) \mathrm{OO}+\mathrm{NO}_{2}+\mathrm{M}
$$

The ventilation coefficients (VC) calculated for winter month (January) as mixed layer height $(\mathrm{MLH}) \times$ wind speed (WS), as illustrated in Fig. 4 show that the maximum $\mathrm{VC}$ is experienced at 9:00 the morning and that is, then, there was a steep rise in the winter period concentration of net $\mathrm{O}_{3}$.

\section{Transport of $\mathrm{O}_{3}$}

Transport of $\mathrm{O}_{3}$ also has a greater implication in the deviation of $P S$ as seen in the period before and after the peak $\mathrm{O}_{3}$ time of the day, wherein the $\mathrm{O}_{3}$ concentrations were always higher than the ratio $\left(J_{1} / k_{3}\right)$. The transport of $\mathrm{O}_{3}$ to the station was examined by comparing (i) the polar plots of $\mathrm{O}_{3}$ and $\mathrm{NO}_{2}$ (for local transport) and (ii) the concentration-weighted trajectories (CWT) of $\mathrm{O}_{3}$ (for regional transport representing the precursors like PAN). The polar plots of $\mathrm{NO}_{2}$ were considered because $\mathrm{O}_{3}$ is ultimately produced (through all photochemical processes) from the photolysis of $\mathrm{NO}_{2}$. If $\mathrm{O}_{3}$ was to be produced only from the photolysis of $\mathrm{NO}_{2}$, the polar plots of $\mathrm{O}_{3}$ and $\mathrm{NO}_{2}$ would look similar. The polar plots of $\mathrm{O}_{3}$ and $\mathrm{NO}_{2}$ are given in Fig. 5, in which the concentrations are plotted against wind speed and wind direction.
Through the seasons, high $\mathrm{O}_{3}$ concentrations were found to accompany high wind speed that suggests transport of $\mathrm{O}_{3}$ to the site (Fig. 5a-d). However, stagnant conditions would also allow locally emitted $\mathrm{NO}$ to titrate the $\mathrm{O}_{3}$. Alternatively, higher concentrations of $\mathrm{NO}_{2}$ were observed under lower wind speeds (Fig. 5e-h). Only moderate and low levels of $\mathrm{NO}_{2}$ were associated with high wind speeds indicating that the $\mathrm{NO}_{\mathrm{x}}$ was locally emitted and dispersed under higher ventilation conditions. It is clear from the plots that higher $\mathrm{O}_{3}$ and higher $\mathrm{NO}_{2}$ were seen to be associated with winds from different directions. It was important to look at the polar plots of the winter season (Fig. 5d, h). As discussed in the previous section, in the winter season, $\mathrm{O}_{3}$ did not show a diel pattern corresponding to $J_{1} / k_{3}(P S)$, and the $\mathrm{O}_{3}$ concentration was much higher than $J_{1} / k_{3}$. The polar plot of $\mathrm{O}_{3}$ in winter shows that $\mathrm{O}_{3}$ was higher when the wind speeds were high, a pattern that is different from the polar plot of $\mathrm{NO}_{2}$. The wind directions with respect to high ozone and the direction with respect to high $\mathrm{NO}_{2}$ were found to be different, which may be inferred as transport of $\mathrm{O}_{3}$ to the site. There are previous reports that during the winter and pre-monsoon seasons, the region receives air mass trajectories that originated and/ or passed over the IGP (Bhuyan et al., 2016; Deka et al., 2020) and bring high pollutant concentrations to the region (Ommi et al., 2017; Rahman et al., 2020).

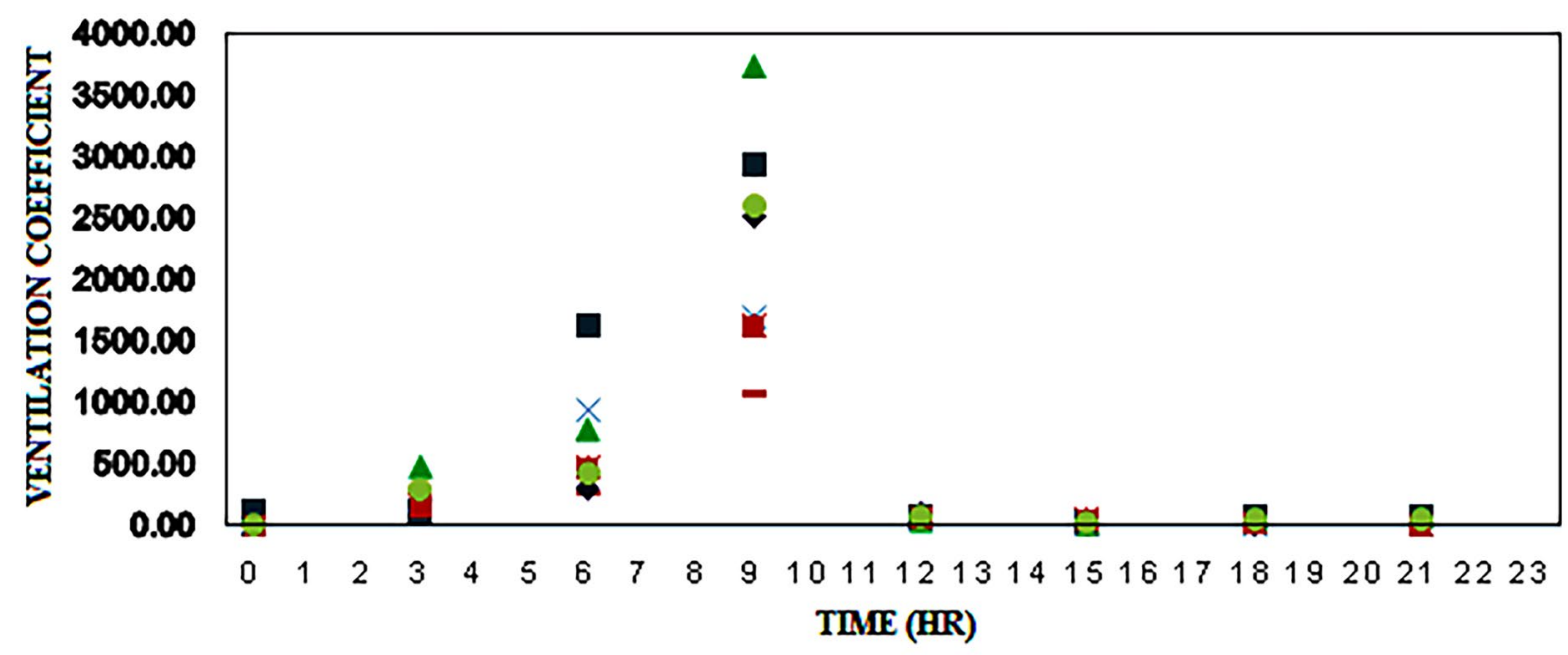

$\longrightarrow$ 02-Jan $\multimap$ 08-Jan $\rightarrow$-12-Jan $\longleftarrow$ 17-Jan $\longleftarrow$ 22-Jan $\rightarrow$-27-Jan $\multimap-30$-Jan

Fig. 4 Ventilation coefficient (VC) during winter period (January 2014). VC was calculated as VC $=\mathrm{MH} \times \mathrm{WS}$; MH was calculated by HYSPLIT 
Fig. 5 Polar plots of $\mathrm{O}_{3}$ (a-d: pre-monsoon, monsoon, post-monsoon, winter), and (b) $\mathrm{NO}_{2}$ (e-h: pre-monsoon, monsoon, post-monsoon, winter): concentrations plotted against wind direction and wind speed during the study period
$\mathrm{O}_{3}$

(a)

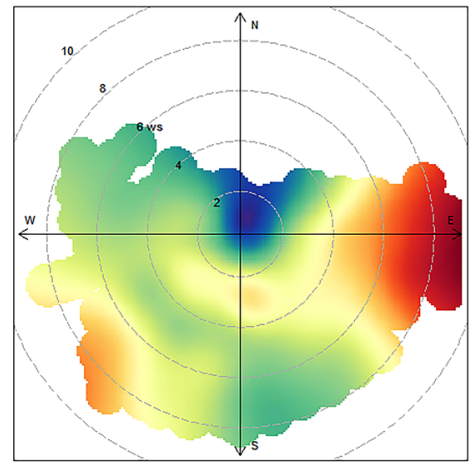

(b)

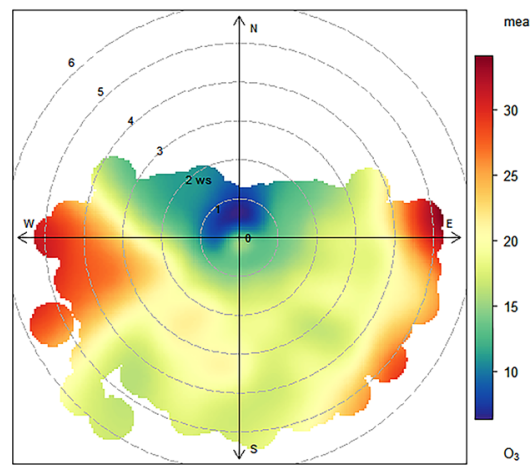

(c)

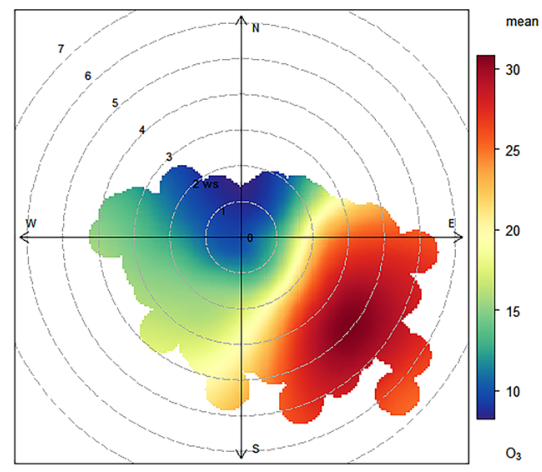

(d)

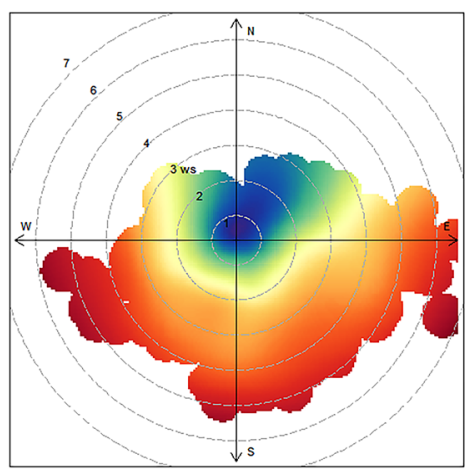

$\mathrm{NO}_{2}$

(e)

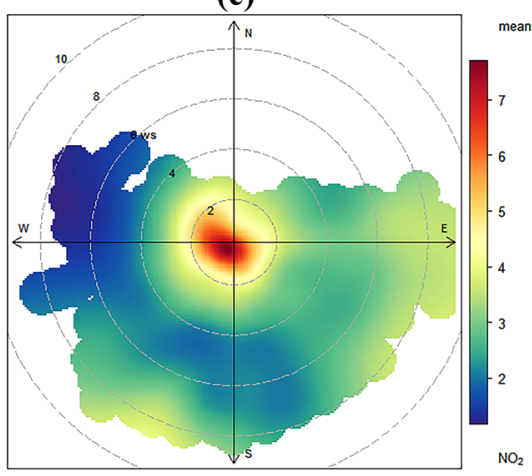

(f)

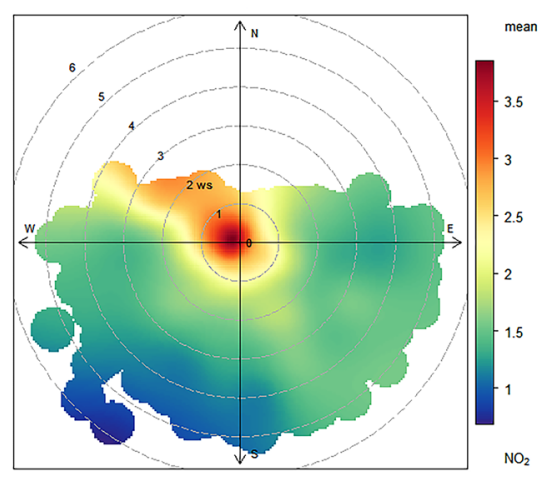

(g)

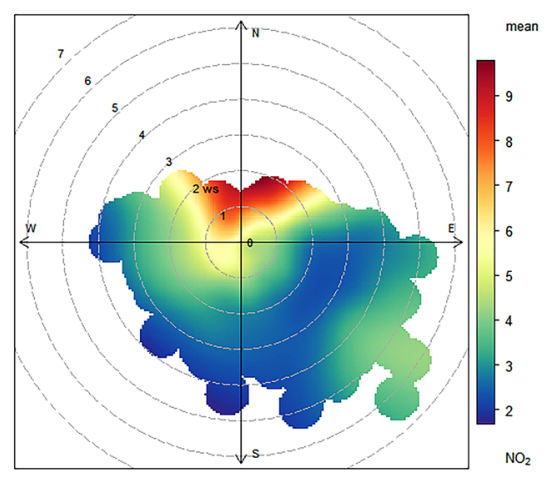

(h)

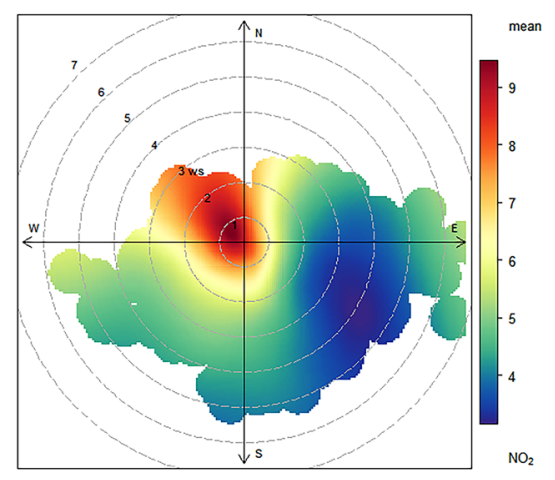




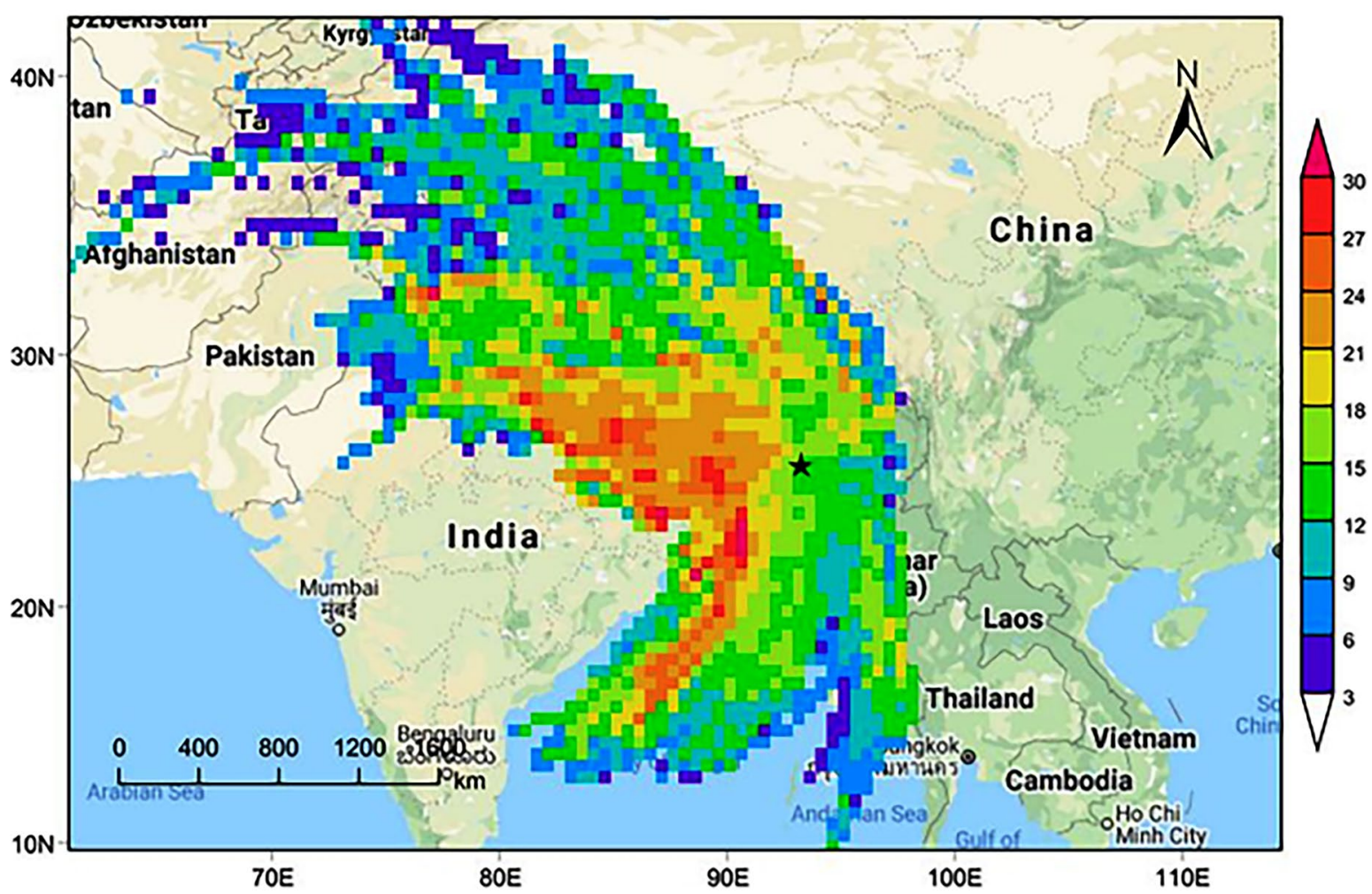

Fig. 6 Concentration-weighted trajectories (CWT) computed from 3-day HYSPLIT back trajectories reaching the site every hour for $\mathrm{O}_{3}$; Tezpur station is shown as the black star

The HYSPLIT air mass trajectories reaching the site were weighted with the concentrations of $\mathrm{O}_{3}$, and the CWTs were computed (Fig. 6). It was clear from the CWT plot that when the trajectories originated or passed over the IGP, the Indian Himalayan region including Nepal, Bangladesh, and the Bay of Bengal, the site experienced higher $\mathrm{O}_{3}$ concentrations (shown as colors above yellow). Moderate concentrations of $\mathrm{O}_{3}$ (color codes green to yellow) were observed when the trajectories originated or passed over Myanmar, the Shillong Plateau, and the western regions of China. These results suggest that the $\mathrm{O}_{3}$ concentrations are strongly affected when the trajectories originated or traveled over polluted regions transporting $\mathrm{O}_{3}$ precursors such as PAN to the area.

\section{Conclusions}

Ambient $\mathrm{O}_{3}$ concentrations of mid-Brahmaputra Valley showed vivid diel, monthly, and seasonal variations, which is not unusual. Ozone concentrations through days and seasons do vary and should vary. However, the behavior of $\mathrm{O}_{3}$ against the $P S$ varied among seasons and $\mathrm{O}_{3}$ of the days of the winter period deviated from the PS substantially. This deviation can be attributed to local emissions from biomass burning, VOCs from both biogenic and anthropogenic emissions, and long-range transport of $\mathrm{O}_{3}$ precursors in the form of PAN and PAN homologues.

Acknowledgements The authors gratefully thank IITM Pune (Ministry of Earth Sciences, GoI) for the setting up of the air quality monitoring station at Tezpur University under the MAPAN programme. The authors also acknowledge other logistics received from Tezpur University and UGC-MANF Fellowship to Warisha Rahman by the UGC, GoI vide order: F1-17.1/2014-15/MANF-2014-15-MUS-ASS-38323.

The authors gratefully acknowledge the NOAA Air Resources Laboratory (ARL) for the provision of the HYSPLIT transport and dispersion model and READY website (http:// www.ready.noaa.gov) used in this publication. The authors also like to acknowledge the free availability of software, Meteoinfo and Trajstat, used in this publication.

Data availability The datasets generated during and/or analyzed during the current study are available from the corresponding author on reasonable request. 


\section{Declarations}

Ethics approval There was no use of animals or animal products at any stage of this work.

Consent to participate There was no involvement of human subjects at any stage of this work.

Consent for publication This paper is an unpublished work and a product of original research. The paper has not been published in any language and not under consideration elsewhere. The authors have agreed to the submission and subsequent publication.

Competing interests The authors declare no competing interests.

\section{References}

Allu, S. K., Srinivasan, S., Maddala, R. K., Reddy, A., \& Anupoju, G. R. (2020). Seasonal ground level ozone prediction using multiple linear regression (MLR) model. Modeling Earth Systems and Environment, 6, 1981-1989.

Altshuller, A. P. (1993). PANs in the atmosphere. Air \& Waste, 43(9), 1221-1230.

Aschmann, S. M., Arey, J., \& Atkinson, R. (2002). OH radical formation from the gas-phase reactions of $\mathrm{O} 3$ with a series of terpenes. Atmospheric Environment, 36(27), 4347-4355.

Atkinson, R. (2000). Atmospheric chemistry of VOCs and NOx. Atmospheric Environment, 34(12-14), 2063-2101.

Atkinson, R., Arey, J., Aschmann, S. M., Corchnoy, S. B., \& Shu, Y. (1995). Rate constants for the gas-phase reactions of cis-3-Hexen-1-ol, cis-3-Hexenylacetate, trans2-Hexenal, and Linalool with $\mathrm{OH}$ and $\mathrm{NO} 3$ radicals and $\mathrm{O} 3$ at $296 \pm 2 \mathrm{~K}$, and $\mathrm{OH}$ radical formation yields from the $\mathrm{O} 3$ reactions. International Journal of Chemical Kinetics, 27(10), 941-955.

Badarinath, K. V. S., Kiran Chand, T. R., \& Krishna Prasad, V. (2009a). Emissions from grassland burning in Kaziranga National Park, India-Analysis from IRS-P6 AWiFS satellite remote sensing datasets. Geocarto International, 24(2), 89-97.

Badarinath, K. V. S., Sharma, A. R., Kharol, S. K., \& Prasad, V. K. (2009b). Variations in $\mathrm{CO}, \mathrm{O}_{3}$ and black carbon aerosol mass concentrations associated with planetary boundary layer (PBL) over tropical urban environment in India. Journal of Atmospheric Chemistry, 62(1), 73-86.

Barletta, B., Meinardi, S., Simpson, I. J., Khwaja, H. A., Blake, D. R., \& Rowland, F. S. (2002). Mixing ratios of volatile organic compounds (VOCs) in the atmosphere of Karachi. Pakistan. Atmospheric Environment, 36(21), 3429-3443.

Bates, D. V. (1989). Ozone--myth and reality. Environmental Research;(USA), 50(2).
Beig, G., Chate, D. M., Ghude, S. D., Mahajan, A. S., Srinivas, R., Ali, K., \& Trimbake, H. R. (2013). Quantifying the effect of air quality control measures during the 2010 Commonwealth Games at Delhi, India. Atmospheric Environment, 80, 455-463.

Beig, G., Gunthe, S., \& Jadhav, D. B. (2007). Simultaneous measurements of ozone and its precursors on a diurnal scale at a semi urban site in India. Journal of Atmospheric Chemistry, 57(3), 239-253.

Bharali, C., Pathak, B., \& Bhuyan, P. K. (2015). Spring and summer night-time high ozone episodes in the upper Brahmaputra valley of North East India and their association with lightning. Atmospheric Environment, 109, 234-250.

Bhuyan, P. K., Bharali, C., Pathak, B., \& Kalita, G. (2014). The role of precursor gases and meteorology on temporal evolution of $\mathrm{O} 3$ at a tropical location in northeast India. Environmental Science and Pollution Research, 21(10), 6696-6713.

Bhuyan, P., Barman, N., Bora, J., Daimari, R., Deka, P., \& Hoque, R. R. (2016). Attributes of aerosol bound water soluble ions and carbon, and their relationships with AOD over the Brahmaputra Valley. Atmospheric Environment, 142, 194-209.

Bhuyan, P., Deka, P., Prakash, A., Balachandran, S., \& Hoque, R. R. (2018). Chemical characterization and source apportionment of aerosol over mid Brahmaputra Valley, India. Environmental Pollution, 234, 997-1010.

Bonasoni, P., Laj, P., Marinoni, A., Sprenger, M., Angelini, F., Arduini, J., \& Cristofanelli, P. (2010). Atmospheric brown clouds in the Himalayas: First two years of continuous observations at the Nepal Climate ObservatoryPyramid (5079 m). Atmospheric Chemistry and Physics, 10(15), 7515-7531.

Carslaw, D.C. (2018). Package "openair". Tools for the Analysis of Air Pollution Data. Available from. http://davidcarslaw. github.io/openair/, Accessed date: February 2018.

Carslaw, D. C., \& Ropkins, K. (2012). Openair-An R package for air quality data analysis. Environmental Modelling \& Software, 27, 52-61.

Census of India. (2011). http://www.censusindia.gov.in/2011prov-results/data_files/delhi/2_PDFC-Paper-1-major_ trends_44-59.pdf

Chameides, W. L., Fehsenfeld, F., Rodgers, M. O., Cardelino, C., Martinez, J., Parrish, D., \& Wang, T. (1992). Ozone precursor relationships in the ambient atmosphere. Journal of Geophysical Research: Atmospheres, 97(D5), 6037-6055.

Chuang, G. C., Yang, Z., Westbrook, D. G., Pompilius, M., Ballinger, C. A., White, C. R., et al. (2009). Pulmonary ozone exposure induces vascular dysfunction, mitochondrial damage, and atherogenesis. American Journal of Physiology. Lung Cellular and Molecular Physiology, 297, L209-L216. https://doi.org/10.1152/ajplung. 00102.2009

Clapp, L. J., \& Jenkin, M. E. (2001). Analysis of the relationship between ambient levels of $\mathrm{O} 3, \mathrm{NO} 2$ and $\mathrm{NO}$ as a function of NOx in the UK. Atmospheric Environment, 35(36), 6391-6405.

Cleveland, W. S., Graedel, T. E., Kleiner, B., \& Warner, J. L. (1974). Sunday and workday variations in 
photochemical air pollutants in New Jersey and New York. Science, 186(4168), 1037-1038.

Coates, J., Mar, K. A., Ojha, N., \& Butler, T. M. (2016). The influence of temperature on ozone production under varying NO x conditions-A modelling study. Atmospheric Chemistry and Physics, 16(18), 11601-11615.

Crutzen, P. J. (1974). Photochemical reactions initiated by and influencing ozone in unpolluted tropospheric air. Tellus, 26(1-2), 47-57.

Crutzen, P. J. (1988). Tropospheric ozone: An overview. Tropospheric ozone, 3-32.

Das K.K. (2015). Study on the production pattern and marketing of rapeseed and mustard cultivation in Assam with special reference to Nagaon district. Ph.D. Thesis, Nagaland University, Medziphema.

Debaje, S. B., Jeyakumar, S. J., Ganesan, K., Jadhav, D. B., \& Seetaramayya, P. (2003). Surface ozone measurements at tropical rural coastal station Tranquebar. India. Atmospheric Environment, 37(35), 4911-4916.

Deka, P., \& Hoque, R. R. (2014). Incremental effect of festive biomass burning on wintertime PM10 in Brahmaputra Valley of Northeast India. Atmospheric Research, 143, 380-391.

Deka, J., Baul, N., Bharali, P., Sarma, K. P., \& Hoque, R. R. (2020). Soil PAHs against varied land use of a small city (Tezpur) of middle Brahmaputra Valley: Seasonality, sources, and long-range transport. Environmental Monitoring and Assessment, 192, 1-14.

Deka, P., \& Hoque, R. R. (2015). Chemical characterization of biomass fuel smoke particles of rural kitchens of South Asia. Atmospheric Environment, 108, 125-132.

Draxler, R. R., \& Hess, G. D. (1998). An overview of the HYSPLIT_4 modelling system for trajectories. Australian Meteorological Magazine, 47(4), 295-308.

Dumka, U. C., Gautam, A. S., Tiwari, S., Mahar, D. S., Attri, S. D., Chakrabarty, R. K., \& Hooda, R. (2020). Evaluation of urban ozone in the Brahmaputra River Valley. Atmospheric Pollution Research, 11(3), 610-618.

Ecotech. (2010). Environmental monitoring, Serinus 10 ozone analyzer, user manual, version 1.4.

Ecotech. (2011). Environmental monitoring, Serinus 40 oxides of Nitrogen analyzer, user manual, version 1.7.

Filella, I., \& Penuelas, J. (2006). Daily, weekly and seasonal relationships among VOCs, NOx and $\mathrm{O}_{3}$ in a semi-urban area near Barcelon Journal of Atmospheric Chemistry, 54(2), 189-201.

Finlayson-Pitts, B. J., \& Pitts, J. N., Jr. (1999). Chemistry of the upper and lower atmosphere: Theory, experiments, and applications. Elsevier.

Fujita, E. M., Stockwell, W. R., Campbell, D. E., Keislar, R. E., \& Lawson, D. R. (2003). Evolution of the magnitude and spatial extent of the weekend ozone effect in California's South Coast Air Basin, 1981-2000. Journal of the Air \& Waste Management Association, 53(7), 802-815.

Gan, J., Yates, S. R., Ohr, H. D., \& Sims, J. J. (1998). Production of methyl bromide by terrestrial higher plants. Geophysical Research Letters, 25(19), 3595-3598.

Ganguly, N. D., \&Tzanis, C. (2013). High surface ozone episodes at New Delhi, India. In On a sustainable future of the earth's natural resources (pp. 445-453). Springer, Berlin, Heidelberg.
Geddes, J. A., Murphy, J. G., \& Wang, D. K. (2009). Long term changes in nitrogen oxides and volatile organic compounds in Toronto and the challenges facing local ozone control. Atmospheric Environment, 43(21), 3407-3415.

Ghude, S. D., Jena, C., Chate, D. M., Beig, G., Pfister, G. G., Kumar, R., \& Ramanathan, V. (2014). Reductions in India's crop yield due to ozone. Geophysical Research Letters, 41(15), 5685-5691.

Gilge, S., Plass-Duelmer, C., Fricke, W., Kaiser, A., Ries, L., Buchmann, B., \& Steinbacher, M. (2010). Ozone, carbon monoxide and nitrogen oxides time series at four alpine GAW mountain stations in central Europe. Atmospheric Chemistry and Physics, 10(24), 12295-12316.

Greiner, N.R. (1967). Hydroxyl-radical kinetics by kinetic spectroscopy. I. Reactions with $\mathrm{H} 2, \mathrm{CO}$, and $\mathrm{CH} 4$ at $300^{\circ}$ K. The Journal of Chemical Physics. 46(7), 2795-2799.

Gu, Y., Li, K., Xu, J., Liao, H., \& Zhou, G. (2020). Observed dependence of surface ozone on increasing temperature in Shanghai, China. Atmospheric Environment, 221, 117108.

Haagen-Smit, A. J. (1952). Chemistry and physiology of Los Angeles smog. Industrial \& Engineering Chemistry, 44(6), 1342-1346.

Han, S., Bian, H., Feng, Y., Liu, A., Li, X., Zeng, F., \& Zhang, X. (2011). Analysis of the relationship between O3, NO and NO2 in Tianjin. China. Aerosol and Air Quality Research, 11(2), 128-139.

Hoque, R. R., \& Deka, P. (2010). Aerosol and CO emissions during meji burning. Current Science, 98(10), 1270.

Hoque, R. R., Khillare, P. S., Agarwal, T., Shridhar, V., \& Balachandran, S. (2008). Spatial and temporal variation of BTEX in the urban atmosphere of Delhi. India. Science of the Total Environment, 392(1), 30-40.

Horticulture Statistics Division, (2018). Horticulture Statistics Division Department of Agriculture. Cooperation \& Farmers' Welfare Ministry of Agriculture and Farmers' Welfare Government of India.

Im, U., Incecik, S., Guler, M., Tek, A., Topcu, S., Unal, Y. S., \& Tayanc, M. (2013). Analysis of surface ozone and nitrogen oxides at urban, semi-rural and rural sites in Istanbul, Turkey. Science of the Total Environment, 443, 920-931.

Intergovernmental Panel on Climate Change, (IPCC). (2013). Technical report, In: Climate change 2013: The physical science basis. Contribution of Working Group I to the Fifth Assessment Report of the Intergovernmental Panel on Climate Change, Cambridge University Press, Cambridge, United Kingdom and New York, NY, USA, 129.

Jia, X., Song, X., Shima, M., Tamura, K., Deng, F., \& Guo, X. (2011). Acute effect of ambient ozone on heart rate variability in healthy elderly subjects. Journal of Exposure Science \& Environmental Epidemiology, 21(5), 541-547.

Kanchana, A. L., Sagar, V. K., Pathakoti, M., Mahalakshmi, D. V., Mallikarjun, K., \&Gharai, B. (2020). Ozone variability: Influence by its precursors and meteorological parameters-An investigation. Journal of Atmospheric and Solar-Terrestrial Physics, 211, 105468.

Karnosky, D. F., Zak, D. R., Pregitzer, K. S., Awmack, C. S., Bockheim, J. G., Dickson, R. E., \& Isebrands, J. G. 
(2003). Tropospheric O3 moderates responses of temperate hardwood forests to elevated $\mathrm{CO}_{2}$ : A synthesis of molecular to ecosystem results from the Aspen FACE project. Functional Ecology, 17(3), 289-304.

Kgabi, N. A., \& Sehloho, R. M. (2012). Seasonal variations of tropospheric ozone concentrations. Global Journal of Science Frontier Research Chemistry, 12, 21-29.

Khalil, M. A. K., Butenhoff, C. L., \& Harrison, R. M. (2018). Ozone balances in urban Saudi Arabia. npj Climate and Atmospheric Science, 1(1), 1-9.

Khillare, P. S., Balachandran, S., \& Hoque, R. R. (2005). Profile of PAH in the exhaust of gasoline driven vehicles in Delhi. Environmental Monitoring and Assessment., 110(1-3), 217-225.

Khillare, P. S., Agarwal, T., \& Shridhar, V. (2008a). Impact of CNG implementation on PAHs concentration in the ambient air of Delhi: A comparative assessment of preand post-CNG scenario. Environmental Monitoring and Assessment, 147(1), 223-233.

Khillare, P. S., Hoque, R. R., Shridhar, V., Agarwal, T., \& Balachandran, S. (2008b). Temporal variability of benzene concentration in the ambient air of Delhi: A comparative assessment of pre-and post-CNG periods. Journal of Hazardous Materials, 154(1-3), 1013-1018.

Khoder, M. I. (2009). Diurnal, seasonal and weekdays-weekends variations of ground level ozone concentrations in an urban area in greater Cairo. Environmental Monitoring and Assessment, 149(1), 349-362.

Kulkarni, P. S., Bortoli, D., Salgado, R., Antón, M., Costa, M. J., \& Silva, A. M. (2011). Tropospheric ozone variability over the Iberian Peninsula. Atmospheric Environment, 45(1), 174-182.

Kuniyal, J. C., Choudhary, S., \& Sharma, P. (2021). Five years surface ozone behaviour in a semi rural location at Mohal-Kullu in the north-western Himalaya, India.

Lal, D. M., Ghude, S. D., Patil, S. D., Kulkarni, S. H., Jena, C., Tiwari, S., \& Srivastava, M. K. (2012). Tropospheric ozone and aerosol long-term trends over the IndoGangetic Plain (IGP), India. Atmospheric Research, 116, 82-92.

Lal, S., Naja, M., \& Subbaraya, B. H. (2000). Seasonal variations in surface ozone and its precursors over an urban site in India. Atmospheric Environment, 34(17), 2713-2724.

Laskar, S. I., Jaswal, K., Bhatnagar, M. K., \& Rathore, L. S. (2016). India meteorological department. Proceedings of the Indian National Science Academy, 82(3), 1021-1037.

Leighton, P. (1961). Photochemistry of air pollution (p. 300). Academies press.

Li, K., Chen, L., Ying, F., White, S. J., Jang, C., Wu, X., \& Cen, K. (2017). Meteorological and chemical impacts on ozone formation: A case study in Hangzhou, China. Atmospheric Research, 196, 40-52.

Ling, Z. H., \& Guo, H. (2014). Contribution of VOC sources to photochemical ozone formation and its control policy implication in Hong Kong. Environmental Science \& Policy, 38, 180-191.

Lippmann, M. (1991). Health effects of tropospheric ozone. Environmental Science \& Technology, 25(12), 1954-1962.
Mead, M. I., White, I. R., Nickless, G., Wang, K. Y., \& Shallcross, D. E. (2008). An estimation of the global emission of methyl bromide from rapeseed (Brassica napus) from 1961 to 2003. Atmospheric Environment, 42(2), 337-345.

Nishanth, T., Praseed, K. M., Satheesh Kumar, M. K., \& Valsaraj, K. T. (2012). Analysis of ground level O3 and $\mathrm{No}_{\mathrm{x}}$ measured at Kannur. India. J Earth Sci Climate Change, 3, 111. https://doi.org/10.4172/2157-7617.1000111

Ommi, A., Emami, F., Zíková, N., Hopke, P. K., \& Begum, B. A. (2017). Trajectory-based models and remote sensing for biomass burning assessment in Bangladesh. Aerosol and Air Quality Research, 17(2), 465-475.

Orlando, J. J., Tyndall, G. S., \& Wallington, T. J. (1996). Atmospheric oxidation of $\mathrm{CH} 3 \mathrm{Br}$ : Chemistry of the $\mathrm{CH} 2 \mathrm{BrO}$ radical. The Journal of Physical Chemistry, 100(17), 7026-7033.

Paffett, M. L., Zychowski, K. E., Sheppard, L., Robertson, S., Weaver, J. M., Lucas, S. N., \& Campen, M. J. (2015). Ozone inhalation impairs coronary artery dilation via intracellular oxidative stress: Evidence for serum-borne factors as drivers of systemic toxicity. Toxicological Sciences, 146(2), 244-253.

Pancholi, P., Kumar, A., Bikundia, D. S., \& Chourasiya, S. (2018). An observation of seasonal and diurnal behavior of O3-NOx relationships and local/regional oxidant (OX $=\mathrm{O} 3+\mathrm{NO} 2$ ) levels at a semi-arid urban site of Western India. Sustainable Environment Research, 28(2), 79-89.

Paoletti, E., De Marco, A., Beddows, D. C., Harrison, R. M., \& Manning, W. J. (2014). Ozone levels in European and USA cities are increasing more than at rural sites, while peak values are decreasing. Environmental Pollution, 192, 295-299.

Pathak, B., Chutia, L., Bharali, C., \& Bhuyan, P. K. (2016). Continental export efficiencies and delineation of sources for trace gases and black carbon in North-East India: Seasonal variability. Atmospheric Environment, 125, 474-485.

Pochanart, P., Hirokawa, J., Kajii, Y., Akimoto, H., \& Nakao, M. (1999). Influence of regional-scale anthropogenic activity in northeast Asia on seasonal variations of surface ozone and carbon monoxide observed at Oki. Japan. Journal of Geophysical Research: Atmospheres, 04(D3), 3621-3631.

Rahman, M. M., Begum, B. A., Hopke, P. K., Nahar, K., \& Thurston, G. D. (2020). Assessing the PM2. 5 impact of biomass combustion in megacity Dhaka, Bangladesh. Environmental Pollution, 264, 114798.

Reddy, B. S. K., Kumar, K. R., Balakrishnaiah, G., Gopal, K. R., Reddy, R. R., Sivakumar, V., \& Lal, S. (2012). Analysis of diurnal and seasonal behavior of surface ozone and its precursors (NOx) at a semi-arid rural site in southern India. Aerosol and Air Quality Research, 12(6), 1081-1094.

Roberts-Semple, D., Song, F., \& Gao, Y. (2012). Seasonal characteristics of ambient nitrogen oxides and groundlevel ozone in metropolitan northeastern New Jersey. Atmospheric Pollution Research, 3(2), 247-257.

Robertson, S., Colombo, E. S., Lucas, S. N., Hall, P. R., Febbraio, M., Paffett, M. L., et al. (2013). CD36 mediates endothelial dysfunction downstream of circulating factors induced by O3 exposure. Toxicological Sciences, 134, 304-311. https://doi.org/10.1093/toxsci/kft107 
Rolph, G., Stein, A., \& Stunder, B. (2017). Real-time environmental applications and display system: READY. Environmental Modelling \& Software, 95, 210-228.

Rubin, J. I., Kean, A. J., Harley, R. A., Millet, D. B., \& Goldstein, A. H. (2006). Temperature dependence of volatile organic compound evaporative emissions from motor vehicles. Journal of Geophysical Research: Atmospheres, 111(D3).

Sarangi, T., Naja, M., Ojha, N., Kumar, R., Lal, S., Venkataramani, S., \& Chandola, H. C. (2014). First simultaneous measurements of ozone, $\mathrm{CO}$, and NOy at a high-altitude regional representative site in the central Himalayas. Journal of Geophysical Research: Atmospheres, 119(3), 1592-1611.

Satsangi, G. S., Lakhani, A., Kulshrestha, P. R., \& Taneja, A. (2004). Seasonal and diurnal variation of surface ozone and a preliminary analysis of exceedance of its critical levels at a semi-arid site in India. Journal of Atmospheric Chemistry, 47(3), 271-286.

Schneider, G. F., Cheesman, A. W., Winter, K., Turner, B. L., Sitch, S., \& Kursar, T. A. (2017). Current ambient concentrations of ozone in Panama modulate the leaf chemistry of the tropical tree Ficus insipida. Chemosphere, $172,363-372$.

Seinfeld, J. H., \& Pandis, S. N. (2016). Atmospheric chemistry and physics, from air pollution to climate change (3rd ed.). John Wiley Sons, Inc.

Sicard, P., De Marco, A., Agathokleous, E., Feng, Z., Xu, X., Paoletti, E., ... \&Calatayud, V. (2020). Amplified ozone pollution in cities during the COVID-19 lockdown. Science of the Total Environment, 735, 139542.

Sikder, H. A., Nasiruddin, M., Suthawaree, J., Kato, S., \& Kajii, Y. (2013). Long term observation of surface $\mathrm{O}_{3}$ and its precursors in Dhaka, Bangladesh. Atmospheric Research, 122, 378-390.

Sillman, S., Logan, J. A., \& Wofsy, S. C. (1990). The sensitivity of ozone to nitrogen oxides and hydrocarbons in regional ozone episodes. Journal of Geophysical Research: Atmospheres, 95(D2), 1837-1851.

Sillman, S. (1999). The relation between ozone, NOx and hydrocarbons in urban and polluted rural environments. Atmospheric Environment, 33(12), 1821-1845.

Sillman, S., \& Samson, P. J. (1995). Impact of temperature on oxidant photochemistry in urban, polluted rural and remote environments. Journal of Geophysical Research: Atmospheres, 100(D6), 11497-11508.

Sillman, S. (1995). The use of NOy, $\mathrm{H}_{2} \mathrm{O}_{2}$, and $\mathrm{HNO} 3$ as indicators for ozone-NO $\mathrm{x}$-hydrocarbon sensitivity in urban locations. Journal of Geophysical Research: Atmospheres, 100(D7), 14175-14188.

Singh, A. A., Fatima, A., Mishra, A. K., Chaudhary, N., Mukherjee, A., Agrawal, M., \& Agrawal, S. B. (2018). Assessment of ozone toxicity among 14 Indian wheat cultivars under field conditions: Growth and productivity. Environmental Monitoring and Assessment, 190(4), 1-14.

Singh, H. B., Kanakidou, M., Crutzen, P. J., \& Jacob, D. J. (1995). High concentrations and photochemical fate of oxygenated hydrocarbons in the global troposphere. Nature, 378(6552), 50-54.

Singla, V., Satsangi, A., Pachauri, T., Lakhani, A., \& Kumari, K. M. (2011). Ozone formation and destruction at a suburban site in North Central region of India. Atmospheric Research, 101(1-2), 373-385.
Squizzato, S., Masiol, M., Rich, D. Q., \& Hopke, P. K. (2018). PM2. 5 and gaseous pollutants in New York State during 2005-2016: Spatial variability, temporal trends, and economic influences. Atmospheric Environment, 183, 209-224.

Srivastava, A., Joseph, A. E., \& Devotta, S. (2006). Volatile organic compounds in ambient air of Mumbai-India. Atmospheric Environment, 40(5), 892-903.

Stedman, D. H., Steffenson, D., \& Niki, H. (1970). The reaction between active hydrogen and $\mathrm{Cl} 2$-evidence for the participation of vibrationally excited H2. Chemical Physics Letters., 7(2), 173-174.

Stein, A. F., Draxler, R. R., Rolph, G. D., Stunder, B. J., Cohen, M. D., \& Ngan, F. (2015). NOAA's HYSPLIT atmospheric transport and dispersion modeling system. Bulletin of the American Meteorological Society, 96(12), 2059-2077.

Steinbrecher, R., Smiatek, G., Köble, R., Seufert, G., Theloke, J., Hauff, K., \& Curci, G. (2009). Intra-and inter-annual variability of VOC emissions from natural and seminatural vegetation in Europe and neighbouring countries. Atmospheric Environment, 43(7), 1380-1391.

Sulaymon, I. D., Zhang, Y., Hopke, P. K., Zhang, Y., Hua, J., \& Mei, X. (2021). COVID-19 pandemic in Wuhan: Ambient air quality and the relationships between criteria air pollutants and meteorological variables before, during, and after lockdown. Atmospheric Research, 250, 105362.

Tabinda, A. B., Munir, S., Yasar, A., \& Ilyas, A. (2016). Seasonal and temporal variations of criteria air pollutants and the influence of meteorological parameters on the concentration of pollutants in ambient air in Lahore, Pakistan. Pakistan Journal of Scientific \& Industrial Research Series a: Physical Sciences, 59(1), 34-42.

Torkmahalleh, M. A., Akhmetvaliyeva, Z., Omran, A. D., Omran, F. D., Kazemitabar, M., Naseri, M., \& Xie, S. (2021). Global air quality and COVID-19 pandemic: Do we breathe cleaner air? Aerosol and Air Quality Research, 21, 1.

Tyagi, B., Singh, J., \& Beig, G. (2020). Seasonal progression of surface ozone and NOx concentrations over three tropical stations in North-East India. Environmental Pollution, 258, 113662.

Udayasoorian, C., Jayabalakrishnan, R. M., Suguna, A. R., Venkataramani, S., \& Lal, S. (2013). Diurnal and seasonal characteristics of ozone and NOx over a high altitude Western Ghats location in Southern India. Advances in Applied Science Research, 4(5), 309-320.

Wałaszek, K., Kryza, M., \& Werner, M. (2018). The role of precursor emissions on ground level ozone concentration during summer season in Poland. Journal of Atmospheric Chemistry, 75(2), 181-204.

Wang, Y. Q., Zhang, X. Y., \& Draxler, R. R. (2009). TrajStat: GIS-based software that uses various trajectory statistical analysis methods to identify potential sources from long-term air pollution measurement data. Environmental Modelling \& Software, 24(8), 938-939.

Wild, O., Pochanart, P., \& Akimoto, H. (2004). Trans-Eurasian transport of ozone and its precursors. Journal of Geophysical Research: Atmospheres, 109(D11). 
Wolff, G. T., Kahlbaum, D. F., \& Heuss, J. M. (2013). The vanishing ozone weekday/weekend effect. Journal of the Air \& Waste Management Association, 63(3), 292-299.

Wu, K., Yang, X., Chen, D., Gu, S., Lu, Y., Jiang, Q., \& Lu, S. (2020). Estimation of biogenic VOC emissions and their corresponding impact on ozone and secondary organic aerosol formation in China. Atmospheric Research, 231, 104656.

Yadav, R., Sahu, L. K., Jaaffrey, S. N. A., \& Beig, G. (2014). Distributions of ozone and related trace gases at an urban site in western India. Journal of Atmospheric Chemistry, 71(2), 125-144.

Young, P. J., Archibald, A. T., Bowman, K. W., Lamarque, J. F., Naik, V., Stevenson, D. S., \& Zeng, G. (2013). Preindustrial to end 21 st century projections of tropospheric ozone from the Atmospheric Chemistry and Climate Model Intercomparison Project (ACCMIP). Atmospheric Chemistry and Physics, 13(4), 2063-2090.

Zhao, K., Hu, C., Yuan, Z., Xu, D., Zhang, S., Luo, H., \& Jiang, R. (2021). A modeling study of the impact of stratospheric intrusion on ozone enhancement in the lower troposphere over the Hong Kong regions, China. Atmospheric Research, 247, 105158.
Zhao, R., Dou, X., Zhang, N., Zhao, X., Yang, W., Han, B., \& Bai, Z. (2020). The characteristics of inorganic gases and volatile organic compounds at a remote site in the Tibetan Plateau. Atmospheric Research, 234, 104740.

Zhang, K., Xu, J., Huang, Q., Zhou, L., Fu, Q., Duan, Y., \& Xiu, G. (2020). Precursors and potential sources of ground-level ozone in suburban Shanghai. Frontiers of Environmental Science \& Engineering, 14, 1-12.

Zunckel, M., Venjonoka, K., Pienaar, J. J., Brunke, E. G., Pretorius, O., Koosialee, A., \& Van Tienhoven, A. M. (2004). Surface ozone over southern Africa: Synthesis of monitoring results during the Cross Border Air Pollution Impact Assessment Project. Atmospheric Environment, 38(36), 6139-6147.

Publisher's Note Springer Nature remains neutral with regard to jurisdictional claims in published maps and institutional affiliations. 